\title{
Investigation of HNCO adsorption and hydrolysis on Fe-ZSM5
}

\author{
Gaia Piazzesi, Daniele Nicosia, Mukundan Devadas, Oliver Kröcher,* Martin Elsener, and Alexander Wokaun \\ Paul Scherrer Institute, Villigen PSI 5232, Switzerland
}

Received 15 February 2007; accepted 16 February 2007

\begin{abstract}
The adsorption of $\mathrm{HNCO}$ on Fe-ZSM5 was investigated in detail by DRIFT spectroscopy and compared to the adsorption on H-ZSM5, $\mathrm{Al}_{2} \mathrm{O}_{3}, \mathrm{SiO}_{2}, \mathrm{Fe}_{2} \mathrm{O}_{3} / \mathrm{Al}_{2} \mathrm{O}_{3}$ and $\mathrm{Fe}_{2} \mathrm{O}_{3} / \mathrm{SiO}_{2}$. At $150{ }^{\circ} \mathrm{C}, \mathrm{HNCO}$ adsorbs dissociatively on $\mathrm{Fe}-\mathrm{ZSM} 5$ producing principally isocyanate species $(-\mathrm{NCO})$ adsorbed on $\mathrm{Al}$ and $\mathrm{Fe}$ sites. In the presence of water the hydrolysis of the $-\mathrm{NCO}$ groups to $\mathrm{NH}_{3}$ was observed. Comparison of the DRIFT results with measurements of the catalytic activity of coated cordierite monoliths suggests that -NCO groups are likely intermediate species in the hydrolysis of HNCO over Fe-ZSM5.
\end{abstract}

KEY WORDS: HNCO adsorption; HNCO hydrolysis; Fe-ZSM5; urea SCR; DeNOx; DRIFT.

\section{Introduction}

The necessity to reduce fuel consumption favors Diesel powered vehicles in the near future, which on the one hand are very fuel efficient but on the other hand require internal measures and/or exhaust gas aftertreatment systems to minimize their inherent nitrogen oxide $\left(\mathrm{NO}_{x}\right)$ and particulate $(\mathrm{PM})$ emissions. The selective catalytic reduction (SCR) process is widely used for the $\mathrm{NO}_{x}$ abatement in stationary power plants, and is also employed for this purpose in Diesel vehicles. Whereas $\mathrm{NH}_{3}$ is used in stationary SCR systems as the most efficient reducing agent for $\mathrm{NO}_{x}$, in Diesel vehicles the use of the non-toxic and easy-to-handle urea $\left(\mathrm{H}_{2} \mathrm{~N}-\right.$ $\mathrm{CO}-\mathrm{NH}_{2}$ ) is preferred as $\mathrm{NH}_{3}$ precursor due to safety reasons [1,2]. The production of $\mathrm{NH}_{3}$ from urea occurs by a thermo-hydrolysis reaction, i.e. the thermal decomposition of urea to isocyanic acid (HNCO) (1), and the hydrolysis of $\mathrm{HNCO}$ to $\mathrm{NH}_{3}$ and $\mathrm{CO}_{2}$ (2). Subsequently, $\mathrm{NH}_{3}$ is reacting with $\mathrm{NO}$ and $\mathrm{O}_{2}$ in the SCR reaction (3).

\subsection{Thermo-hydrolysis of urea}

$$
\begin{gathered}
\mathrm{NH}_{2} \mathrm{CONH}_{2} \rightarrow \mathrm{HNCO}+\mathrm{NH}_{3} \\
\mathrm{HNCO}+\mathrm{H}_{2} \mathrm{O} \rightarrow \mathrm{NH}_{3}+\mathrm{CO}_{2}
\end{gathered}
$$

\section{2. $S C R$ reaction}

$$
4 \mathrm{NO}+4 \mathrm{NH}_{3}+\mathrm{O}_{2} \rightarrow 4 \mathrm{~N}_{2}+6 \mathrm{H}_{2} \mathrm{O}
$$

\footnotetext{
*To whom correspondence should be addressed. E-mail: oliver.kroecher@psi.ch
}

While the thermal decomposition of urea (1) is a fast reaction, the hydrolysis of isocyanic acid (2) as well as the SCR reaction (3) require a catalyst to proceed efficiently. The catalyst usually employed for the SCR process is $\mathrm{V}_{2} \mathrm{O}_{5}$ supported on $\mathrm{TiO}_{2}$ promoted by $\mathrm{WO}_{3}$, which accelerates both reaction (2) and (3). However, concerns about the potential toxicity of vanadium oxide is opposed to its use and in the near future non-toxic materials will have to be employed [3]. Recently, Fe-ZSM5 received much attention as such a non-poisonous material, which proved to be highly active for the SCR reaction (see for example [4-9]).

Despite the increasing knowledge about the SCR reaction on Fe-ZSM5, only very little information is available about the preceding HCNO hydrolysis occurring on Fe-supported catalysts $[10,11]$. Solymosi et al. investigated the HNCO adsorption, but specifically on $\mathrm{Cu}-Z \mathrm{ZSM} 5$ and hydrolysis was no issue in this study [12].

We present here results on the catalytic hydrolysis of HNCO on Fe-ZSM5 as promising urea-SCR catalyst for Diesel vehicle applications and contribute to the mechanistic understanding of the reaction under consideration of the distributed information in the literature [12-18]. The study has been carried out by means of DRIFT spectroscopy in order to observe the surface species formed upon adsorption of HNCO. To facilitate the interpretation of the spectroscopic data, we first compared the results obtained for Fe-ZSM5 with those obtained for the base material H-ZSM5 as well as its components $\mathrm{SiO}_{2}$ and $\mathrm{Al}_{2} \mathrm{O}_{3}$. Finally, a comparison with the $\mathrm{Fe}$-containing samples $\mathrm{Fe}_{2} \mathrm{O}_{3}, \mathrm{Fe}_{2} \mathrm{O}_{3} / \mathrm{SiO}_{2}$, and $\mathrm{Fe}_{2} \mathrm{O}_{3} / \mathrm{Al}_{2} \mathrm{O}_{3}$ was performed. The hydrolysis activity of $\mathrm{Fe}-\mathrm{ZSM} 5$ was also investigated both in the presence and in the absence of $\mathrm{NO}$ and $\mathrm{NO}_{2}$, since these compounds are present in the diesel exhaust gas. The supplemental investigation of the $\mathrm{HNCO}$ adsorption on $\mathrm{SiO}_{2}$ showed 
features that agree well with published theoretical results [19].

\section{Experimental}

The following base materials were used: H-ZSM5 with a $\mathrm{Si} / \mathrm{Al}$ ratio of $28, \mathrm{SiO}_{2}$ (Grace), $\mathrm{Al}_{2} \mathrm{O}_{3}$ (Wacker) and $\mathrm{Fe}_{2} \mathrm{O}_{3}$ (Sigma Aldrich). Over-exchanged Fe-ZSM5 was prepared from H-ZSM5 by solid-state ion exchange with $\mathrm{FeCl}_{2}$ according to [20]. After preparation, the samples were calcined at $550{ }^{\circ} \mathrm{C}$ for $5 \mathrm{~h}$. The amount of iron loaded on the samples was measured by ICP-AES using a Varian Vista AX spectrometer: iron content $=11.4 \mathrm{wt} . \%$.

A Micromeritics ASAP 2000 analyzer was used to measure the $\mathrm{N}_{2}$ adsorption isotherms of the samples. Micropore volume of $\mathrm{H}-\mathrm{ZSM} 5=0.11 \mathrm{~cm}^{3} / \mathrm{g}$. Micropore volume of Fe-ZSM5 $=0.08 \mathrm{~cm}^{3} / \mathrm{g}$.

Iron oxide supported on $\mathrm{SiO}_{2}$ and $\mathrm{Al}_{2} \mathrm{O}_{3}$ was prepared by impregnation of $0.5 \mathrm{~g}$ of each oxide with a $0.1 \mathrm{M} F e\left(\mathrm{NO}_{3}\right)_{3} * 9 \mathrm{H}_{2} \mathrm{O}$ solution and subsequent decomposition of the labile nitrate overnight in air at $100{ }^{\circ} \mathrm{C}$. The iron species formed on the surface of the samples were investigated at 20 and $-150{ }^{\circ} \mathrm{C}$ by EPR spectroscopy using an ELEXYS Bruker instrument (at $\mathrm{X}$-band microwave frequency). The experiments were carried out on the fresh samples without performing any further treatment.

The activity of the catalysts was tested in form of coated cordierite monoliths (volume $7.5 \mathrm{~cm}^{3}$, active mass $\sim 0.8 \mathrm{~g}$ ) in a glass tubular reactor. The monoliths were coated by immersions in a slurry containing of $0.5 \mathrm{~g}$ of catalyst in $2 \mathrm{~cm}^{3}$ of a $0.5 \mathrm{M} \mathrm{Al}\left(\mathrm{NO}_{3}\right)_{3} \cdot 9 \mathrm{H}_{2} \mathrm{O}$ solution. The samples were then dried at room temperature for $2 \mathrm{~h}$ and, finally, calcined at $500{ }^{\circ} \mathrm{C}$ for $5 \mathrm{~h}$. Before the start of the experiments, the samples were treated at $450{ }^{\circ} \mathrm{C}$ for $1 \mathrm{~h}$ in a flow of $\mathrm{N}_{2} / \mathrm{O}_{2}$. Isocyanic acid was generated by depolymerization of cyanuric acid as described in [21]. HNCO produced by this method contained $\mathrm{NH}_{3}$ as impurity $(2-4 \%$ of the $\mathrm{HNCO}$ concentration). The gaseous reaction products were detected and quantified by FTIR spectroscopy according to the experimental set-up and methods described in [21]. A GHSV of 52,000 $\mathrm{h}^{-1}$ was used for the tests and the inlet flow was composed of $\approx 1000 \mathrm{ppm} \mathrm{HNCO}, 2.5 \% \mathrm{H}_{2} \mathrm{O}$, and $10 \% \mathrm{O}_{2}$ with $\mathrm{N}_{2}$ balance. The effect of $\mathrm{NO}$ was investigated by adding $700 \mathrm{ppm} \mathrm{NO}$ to the inlet flow, while the effect of $\mathrm{NO}_{2}$ was studied by combined addition of $350 \mathrm{ppm} \mathrm{NO}$ and $350 \mathrm{ppm} \mathrm{NO}_{2}$.

The adsorption of $\mathrm{HNCO}$ on the catalyst surfaces was investigated by means of DRIFT spectroscopy. The experiments were carried out with a Nexus FTIR instrument from ThermoNicolet equipped with a Smart Collector DRIFT cell. All spectra were measured by averaging 200 scans at a resolution of $4 \mathrm{~cm}^{-1}$. Before adsorption, the samples were pre-treated at $450{ }^{\circ} \mathrm{C}$ in an
$\mathrm{N}_{2}$ flow for $1 \mathrm{~h}$. The spectral background were collected, and then subtracted from the raw spectra in order to analyze only the adsorbed surface species. For DRIFT investigations the isocyanic acid was purified on a bed of phosphorus pentoxide, yielding $70 \mathrm{ppm} \mathrm{HNCO}$ and $<0.5 \mathrm{ppm} \mathrm{NH}_{3}$. The concentrations of $\mathrm{HNCO}$ and $\mathrm{NH}_{3}$ were measured with an ion analyzer as described in [22]. Adsorption of isocyanic acid was performed for $30 \mathrm{~min}$ at $150{ }^{\circ} \mathrm{C}$, followed by a flow of pure $\mathrm{N}_{2}$ for $30 \mathrm{~min}$ and a final temperature ramp. The stability of the adsorbed species to water was tested by, first, adsorbing $\mathrm{HNCO}$ for $15 \mathrm{~min}$, after which a $\mathrm{H}_{2} \mathrm{O} / \mathrm{N}_{2}$ mixture $\left(41_{N} / h\right.$, saturated at RT) was dosed for $10 \mathrm{~min}$ at $150{ }^{\circ} \mathrm{C}$.

\section{Results}

\subsection{Characterization of iron exchanged catalysts}

The iron adsorbed on the samples is present in form of different species. EPR experiments were carried out to characterize the $\mathrm{Fe}^{3+}$ species only, since $\mathrm{Fe}^{2+}$ is diamagnetic and thereby EPR-silent. EPR investigation of Fe-ZSM5 revealed signals at $\mathrm{g} \sim 8.5, \mathrm{~g} \sim 5.6, \mathrm{~g} \sim 4.3$, $\mathrm{g} \sim 2.3$ (broad), and $\mathrm{g} \sim 2$ (figure $1 \mathrm{~A}$ ). These signals were attributed to isolated $\mathrm{Fe}^{3+}$ sites in strong rhombic or axial distortion, which are incorporated in tetrahedral or octahedral geometry ( $\mathrm{g} \sim 4.3$ and $\mathrm{g}>6$ ). The signal at $\mathrm{g} \sim 5.6$ corresponds to isolated $\mathrm{Fe}^{3+}$ species in higher $\mathrm{Fe}-\mathrm{O}$ coordination number, whereas the signal at $\mathrm{g} \sim 2$ corresponds to isolated $\mathrm{Fe}^{3+}$ ions in positions of high symmetry or bulk $\mathrm{Fe}_{x} \mathrm{O}_{y}$. The broad line at $\mathrm{g} \sim 2.3$ refers to $\mathrm{Fe}_{2} \mathrm{O}_{3}$ particles in the few nanometer range. The detailed peak assignment is reported in [23].

The iron species formed on $\mathrm{Fe}_{2} \mathrm{O}_{3} / \mathrm{SiO}_{2}, \mathrm{Fe}_{2} \mathrm{O}_{3} /$ $\mathrm{Al}_{2} \mathrm{O}_{3}$, and $\mathrm{Fe}_{2} \mathrm{O}_{3}$ were also investigated by EPR experiments and the results are shown in figure 2. For pure iron oxide a signal at $\mathrm{g} \sim 2.3$ was detected. This signal vanished at very low temperatures (figure $2 \mathrm{~A}$ ),

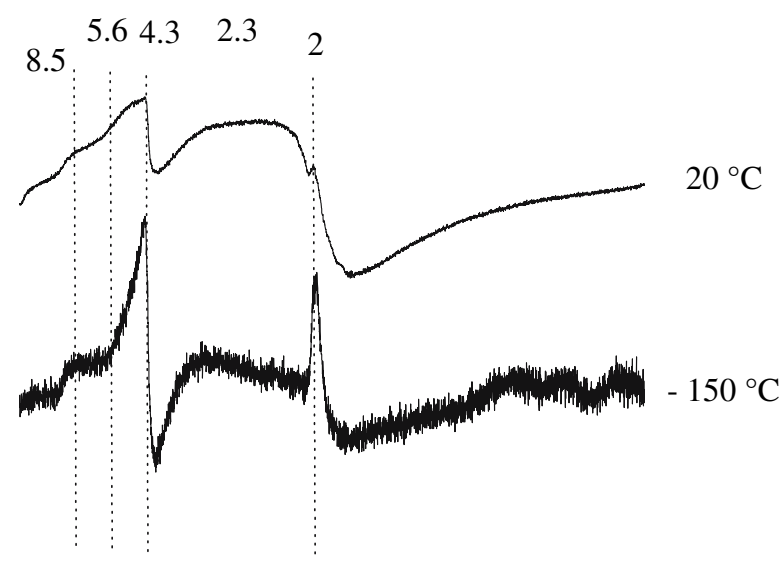

Figure 1. EPR spectra of Fe-ZSM5 $5_{1}$ at $20^{\circ} \mathrm{C}$ and $-133{ }^{\circ} \mathrm{C}$, respectively. 
A

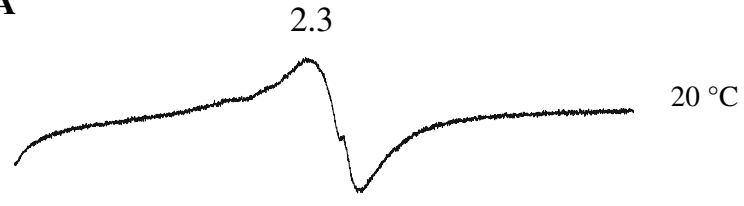

$-150{ }^{\circ} \mathrm{C}$

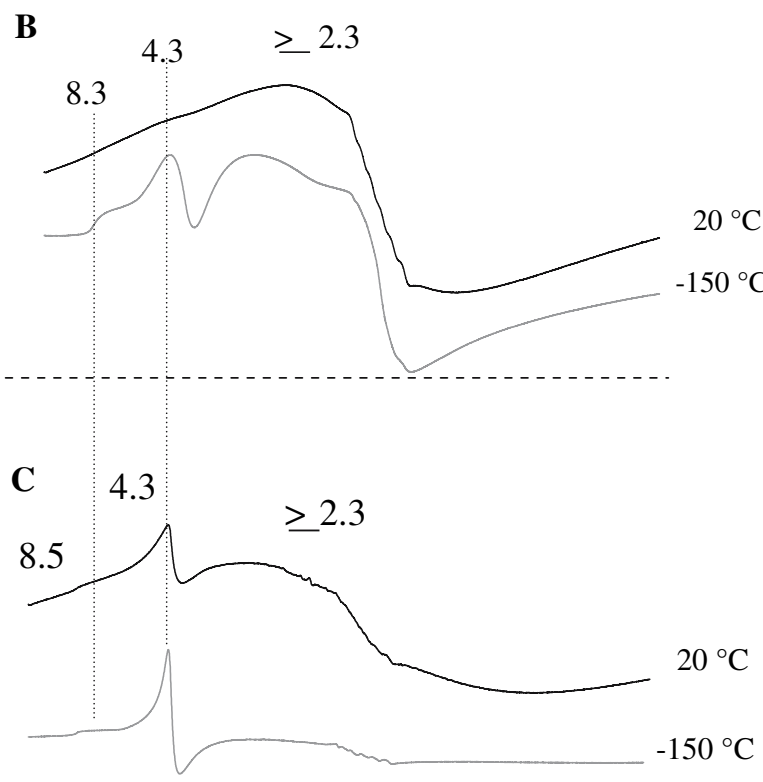

Figure 2. EPR spectra of (A) $\mathrm{Fe}_{2} \mathrm{O}_{3},(\mathrm{~B}) \mathrm{Fe}-\mathrm{SiO}_{2}$ and (C) $\mathrm{Fe}-\mathrm{Al}_{2} \mathrm{O}_{3}$ at $20{ }^{\circ} \mathrm{C}$ and $-133^{\circ} \mathrm{C}$, respectively.

and is typical for $\mathrm{Fe}^{3+}$ in the bulk $\mathrm{Fe}_{2} \mathrm{O}_{3}$. In the EPR spectrum of $\mathrm{Fe}_{2} \mathrm{O}_{3} / \mathrm{SiO}_{2}$ three main signals are visible at $\mathrm{g} \sim 8.3, \mathrm{~g} \sim 4.3$, and $\mathrm{g} \geq 2.3$ (broad). The intensity of the transitions at $\mathrm{g} \sim 8.3$ and $\mathrm{g} \sim 4.3$ increased at lower temperatures, which is typical for paramagnetic species. These signals suggest the presence of isolated $\mathrm{Fe}^{3+}$ ions with distorted tetrahedral or octahedral coordination [24-26]. The broad signal at $\mathrm{g} \geq 2.3$ decreased in intensity and was shifted to lower magnetic fields at $-150{ }^{\circ} \mathrm{C}$, thus it does not follow Curie's law. This signal can be attributed to small iron oxide clusters. The analog EPR spectrum obtained for $\mathrm{Fe}_{2} \mathrm{O}_{3} / \mathrm{Al}_{2} \mathrm{O}_{3}$ indicates that the same $\mathrm{Fe}^{3+}$ species were formed on this material. However, the concentration of the $\mathrm{Fe}^{3+}$ species was obviously different due to the different signal intensities.

In the presence of water and oxygen iron tends to form ill-defined mixed oxide and hydroxide species of the form $\mathrm{Fe}_{x} \mathrm{O}_{y}(\mathrm{OH})_{z}$. Thus, the notation Fe-ZSM5, $\mathrm{Fe}_{2} \mathrm{O}_{3} / \mathrm{SiO}_{2}$, and $\mathrm{Fe}_{2} \mathrm{O}_{3} / \mathrm{Al}_{2} \mathrm{O}_{3}$ does not express the actual structural variety of the iron in these samples as revealed by EPR.

\subsection{Adsorption of $\mathrm{HNCO}$ on $\mathrm{SiO}_{2}$}

During the adsorption of isocyanic acid on $\mathrm{SiO}_{2}$ three infrared adsorption bands evolved (figure 3). At the beginning of the adsorption (spectrum not shown), only

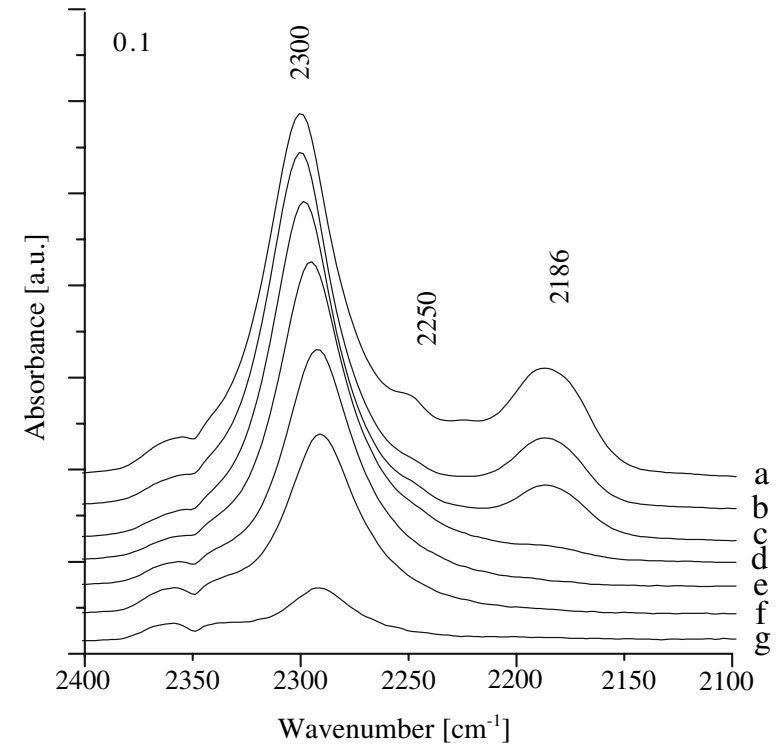

Figure 3. DRIFT spectra of $\mathrm{SiO}_{2}$ after (a) $\mathrm{HNCO}$ adsorption at $150{ }^{\circ} \mathrm{C}$ for $30 \mathrm{~min}$ followed by (b) purging at $150{ }^{\circ} \mathrm{C}$ in $\mathrm{N}_{2}$ for $30 \mathrm{~min}$, increasing the temperature to (c) $200{ }^{\circ} \mathrm{C}$, (d) $300{ }^{\circ} \mathrm{C}$, (e) $400{ }^{\circ} \mathrm{C}$, (f) $450{ }^{\circ} \mathrm{C}$ and (g) purging at $450{ }^{\circ} \mathrm{C}$ for $60 \mathrm{~min}$.

bands at 2250 and $2186 \mathrm{~cm}^{-1}$ appeared, but after a few minutes a band at $2300 \mathrm{~cm}^{-1}$ increased in intensity and rapidly become the most intense. This band was not influenced by purging with nitrogen at $150^{\circ} \mathrm{C}$ and higher temperatures only slightly affected its intensity. It was necessary to purge the sample at $450{ }^{\circ} \mathrm{C}$ for an extended period of time $(60 \mathrm{~min})$ to significantly affect this peak. The bands at 2250 and $2186 \mathrm{~cm}^{-1}$ were less stable and vanished completely already after purging with nitrogen at $150{ }^{\circ} \mathrm{C}$ and $300{ }^{\circ} \mathrm{C}$, respectively. In previous works on the $\mathrm{HNCO}$ adsorption on $\mathrm{SiO}_{2}$ the formation of a band at $2300-2313 \mathrm{~cm}^{-1}$ was reported $[12,14,16,18]$. This band was not observed when adsorption was carried out at $\mathrm{T}<25^{\circ} \mathrm{C}$, but became more intense at higher adsorption temperatures and could only be removed by long purging at high temperature. Considering these literature results, the peak at $2300 \mathrm{~cm}^{-1}$ can be attributed to the Si-NCO groups for its position and temperature stability. The band at $2250 \mathrm{~cm}^{-1}$ might be ascribed to the asymmetric $v_{a}$ vibration of molecularly adsorbed $\mathrm{HNCO}$ due to its position and its poor stability. The $v_{2}$ vibration of HNCO is $2274 \mathrm{~cm}^{-1}$ in the gas phase and $2246 \mathrm{~cm}^{-1}$ in the solid phase [27]. Bánsági et al. also found evidence for molecularly adsorbed $\mathrm{HNCO}$ on $\mathrm{SiO}_{2}$ at room temperature [18]. While in the above mentioned studies only one or two bands are described arising after adsorption of $\mathrm{HNCO}$ on $\mathrm{SiO}_{2}$, our spectrum in figure 3 shows a new additional band at $2186 \mathrm{~cm}^{-1}$, that might be attributed to a $\mathrm{Si}-\mathrm{O}-\mathrm{NCO}$ surface species. This is in good agreement with Ferullo et al. who calculated these IR bands for adsorbed NCO on silica [19]. Such a band was not detected in previous studies of $\mathrm{HNCO}$ 
adsorption on $\mathrm{SiO}_{2}$ and, differently from the present study, the $\mathrm{Si}-\mathrm{NCO}$ band at $2300 \mathrm{~cm}^{-1}$ was also observed at RT. In order to prove our results the investigation was repeated with silica from other companies, resulting in the same bands. In previous studies the silica was pretreated at $450{ }^{\circ} \mathrm{C}$ in vacuum whereas only temperature treatment at $450{ }^{\circ} \mathrm{C}$ was applied by us. Based on this difference it might be speculated that a higher concentration of $\mathrm{OH}$ groups was present on the silica used in our work, preventing the HNCO dissociation at RT and facilitating the formation of the $\mathrm{Si}-\mathrm{O}$ $\mathrm{NCO}$ group.

\subsection{HNCO adsorption on Fe-ZSM5}

Dosing of HNCO for $30 \mathrm{~min}$ over Fe-ZSM5 at $150{ }^{\circ} \mathrm{C}$ (figure 4A) resulted in the formation of bands at 2278 and $2212 \mathrm{~cm}^{-1}$ and small bands at 2139 and $2126 \mathrm{~cm}^{-1}$. At the beginning of the treatment (spectra not shown here), the peaks at 2278 and $2212 \mathrm{~cm}^{-1}$ grew much faster in intensity upon $\mathrm{HNCO}$ dosing than the peaks at 2139 and $2126 \mathrm{~cm}^{-1}$. After degassing with nitrogen for $30 \mathrm{~min}$ at $150^{\circ} \mathrm{C}$ (figure $4 \mathrm{~A}$, spectrum a) the band at $2278 \mathrm{~cm}^{-1}$ attenuated significantly and disappeared completely while purging at $300^{\circ} \mathrm{C}$. By comparing the position and stability of the IR bands with those obtained for H-ZSM5 both from our experiments (not shown) and from literature data [12], the peak at

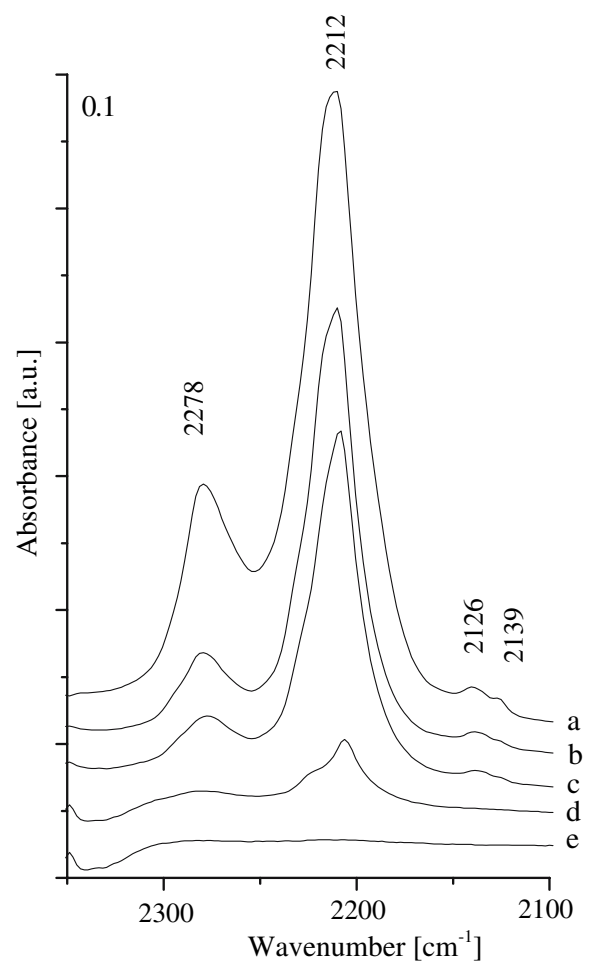

Figure 4. DRIFT spectra of Fe-ZSM5 after (a) HNCO adsorption at $150{ }^{\circ} \mathrm{C}$ for $30 \mathrm{~min}$ followed by (b) purging at $150{ }^{\circ} \mathrm{C}$ in $\mathrm{N}_{2}$ for $30 \mathrm{~min}$ and increasing the temperature to (c) $200{ }^{\circ} \mathrm{C}$, (d) $300{ }^{\circ} \mathrm{C}$ and (e) $400{ }^{\circ} \mathrm{C}$. $\sim 2278 \mathrm{~cm}^{-1}$ can be attributed to the formation of Al$\mathrm{NCO}$ groups. However, regarding the slight asymmetry of this band, the presence of -NCO species adsorbed on different Al sites (tetrahedrally and octahedrally coordinated) as suggested by Bion et al. [13] cannot be ruled out. The small signals at $\sim 2126$ and $2139 \mathrm{~cm}^{-1}$ can be attributed to the formation of cyanate ions $\left([\mathrm{NCO}]^{-}\right)$ $[16,28]$ or cyanide groups $\left(\mathrm{CN}^{-}\right)$[29]. Adsorption experiments with $\mathrm{HCN}$ are in progress to better identify this signal. For the interpretation of the signal at $\sim 2212 \mathrm{~cm}^{-1}$ comparing adsorption experiments on $\mathrm{Fe}_{2} \mathrm{O}_{3} / \mathrm{Al}_{2} \mathrm{O}_{3}$ and $\mathrm{Fe}_{2} \mathrm{O}_{3} / \mathrm{SiO}_{2}$ were carried out, as reported in the next paragraph.

Figure 3 depicts only the spectral range from 2100 to $2400 \mathrm{~cm}^{-1}$ for a better assignment of the peaks related to $\mathrm{HNCO}$ adsorption. However, it has to be mentioned that additional bands at 3370, 3274, 1654 and $1465 \mathrm{~cm}^{-1}$ indicate the adsorption of $\mathrm{NH}_{3}$ and that the strong negative peaks in the $\mathrm{OH}$ region indicate the consumption of surface $\mathrm{OH}$ groups by interaction with $\mathrm{NH}_{3}$ [30].

The adsorption experiments were repeated at $300{ }^{\circ} \mathrm{C}$ and the same bands were formed as those observed at $150{ }^{\circ} \mathrm{C}$. However, the peak intensities were drastically lowered (in particular the peaks at $\sim 2278,2139$ and $2126 \mathrm{~cm}^{-1}$ ) and they were completely removed after short purging with nitrogen.

\subsection{Adsorption of $\mathrm{HNCO}$ on $\mathrm{Fe}_{2} \mathrm{O}_{3}, \mathrm{Fe}_{2} \mathrm{O}_{3} / \mathrm{Al}_{2} \mathrm{O}_{3}$, and $\mathrm{Fe}_{2} \mathrm{O}_{3} / \mathrm{SiO}_{2}$}

The adsorption of $\mathrm{HNCO}$ on $\mathrm{Fe}_{2} \mathrm{O}_{3}$ resulted in the formation of an asymmetric band at $2206 \mathrm{~cm}^{-1}$ that grew and shifted to $2212 \mathrm{~cm}^{-1}$ in the course of the experiment (figure 5A). The band decreased after 30 min of degassing with $\mathrm{N}_{2}$ at $150{ }^{\circ} \mathrm{C}$ and disappeared when the temperature was increased to $300{ }^{\circ} \mathrm{C}$. Various studies showed that HNCO adsorbs mainly dissociatively on transition metal oxides thus forming isocyanate species bound to Lewis acid sites [14,29,31,32]. These isocyanate groups show vibrational bands in the range $2200-2300 \mathrm{~cm}^{-1}$. Therefore, it is plausible to attribute the band at $2212 \mathrm{~cm}^{-1}$ to $\mathrm{Fe}-\mathrm{NCO}$ groups.

Adsorption of $\mathrm{HNCO}$ on $\mathrm{Fe}_{2} \mathrm{O}_{3} / \mathrm{Al}_{2} \mathrm{O}_{3}$ (Fe content $=9.7 \mathrm{wt} \%$ as detected by ICP-AES) produced bands at 2256 and $2200 \mathrm{~cm}^{-1}$ (figure 5B). The former band showed lower intensity and less thermal stability than the second one and vanished completely already at $300{ }^{\circ} \mathrm{C}$. The band at $2200 \mathrm{~cm}^{-1}$ was still present at $400{ }^{\circ} \mathrm{C}$, but it was very weak and was completely removed after a few minutes of purging at this temperature. By comparing these results with those obtained for pure $\mathrm{Al}_{2} \mathrm{O}_{3}$ (not shown) and $\mathrm{Fe}_{2} \mathrm{O}_{3}$ (figure 5A), these two bands can be assigned to $\mathrm{Al}-\mathrm{NCO}$ and $\mathrm{Fe}-\mathrm{NCO}$ species, respectively.

When $\mathrm{HNCO}$ was dosed over $\mathrm{Fe}_{2} \mathrm{O}_{3} / \mathrm{SiO}_{2}$ (Fe content $=9.3 \mathrm{wt} \%$ as detected by ICP-AES) a band at $2202 \mathrm{~cm}^{-1}$ was formed that became very intense and 


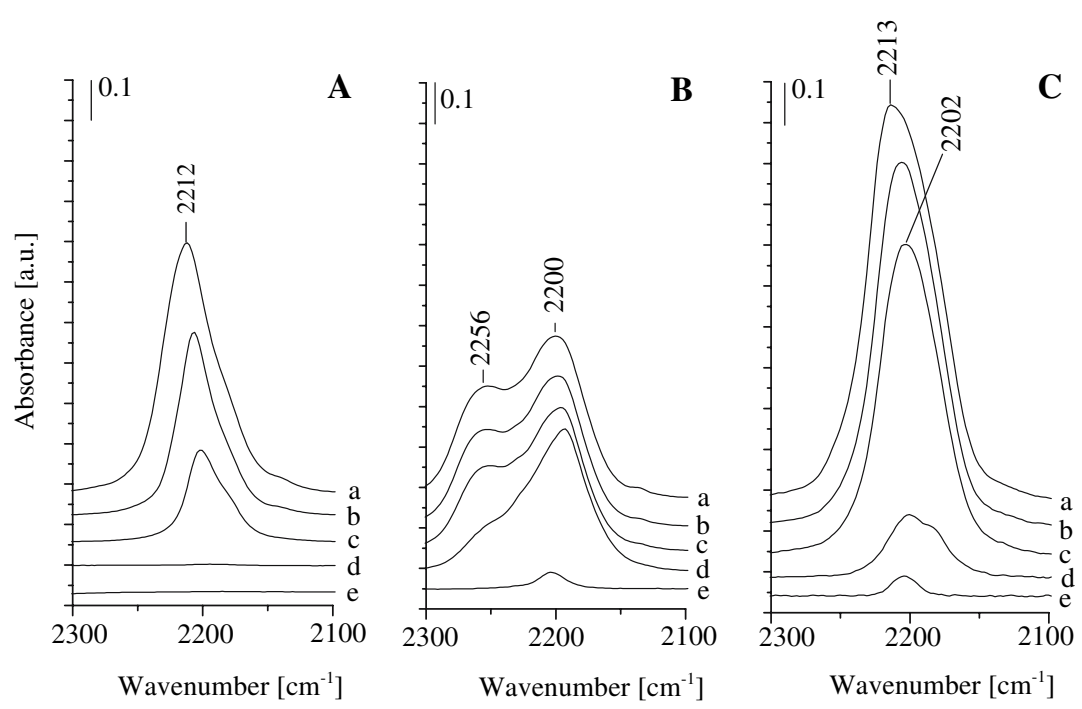

Figure 5. DRIFT spectra of (A) $\mathrm{Fe}_{2} \mathrm{O}_{3}$, (B) $\mathrm{Fe} / \mathrm{Al}_{2} \mathrm{O}_{3}$ and (C) $\mathrm{Fe} / \mathrm{SiO}_{2}$ after (a) $\mathrm{HNCO}$ adsorption at $150{ }^{\circ} \mathrm{C}$ for 30 min followed by (b) purging at $150{ }^{\circ} \mathrm{C}$ in $\mathrm{N}_{2}$ for $30 \mathrm{~min}$ and increasing the temperature to (c) $200{ }^{\circ} \mathrm{C}$, (d) $300{ }^{\circ} \mathrm{C}$ and (e) $400{ }^{\circ} \mathrm{C}$.

shifted to $2213 \mathrm{~cm}^{-1}$ at the end of the adsorption (figure 5C). Purging with nitrogen at $150{ }^{\circ} \mathrm{C}$ for $30 \mathrm{~min}$ decreased the intensity of the band and shifted it to $2202 \mathrm{~cm}^{-1}$. The intensity of this band further decreased at higher temperatures and disappeared at $400{ }^{\circ} \mathrm{C}$. In agreement with the previous observations, this band is ascribed to the $-\mathrm{NCO}$ species adsorbed on iron sites. Remarkably, no $\mathrm{Si}-\mathrm{NCO}$ species were observed usually present at $\sim 2300 \mathrm{~cm}^{-1}$ in the DRIFT spectra.

\subsection{Stability of adsorbed HNCO species in the presence of water}

The stability of the HNCO species adsorbed on Fe-ZSM5 upon water was also investigated. In general, the presence of water in the inlet flow reduced the intensity of the IR bands associated with adsorbed HNCO species (in particular the band at $\sim 2200$ $2212 \mathrm{~cm}^{-1}$ ) and increased the intensity of the bands attributed to adsorbed $\mathrm{NH}_{3}\left(3370,3274,1465 \mathrm{~cm}^{-1}\right)$ (figure 6). The intense negative peaks visible in figure 7 in the $\mathrm{OH}$ region are attributable to the adsorption of $\mathrm{NH}_{3}$ on Brønsted acid sites. No additional bands were formed during water addition in the range typical for adsorbed HNCO species.

\subsection{Catalytic activity}

The catalytic activities of Fe-ZSM5, the pure $\mathrm{H}$-ZSM5 base material, and $\mathrm{Fe}_{2} \mathrm{O}_{3}$ were tested for HNCO hydrolysis (figure 7). For all samples, 100\% selectivity to ammonia was always observed. Fe-ZSM5 showed a much higher activity than H-ZSM5 and $\mathrm{Fe}_{2} \mathrm{O}_{3}$, which is clearly discernible below $300{ }^{\circ} \mathrm{C}$. Interesting enough hydrothermal ageing at $650{ }^{\circ} \mathrm{C}$ for $5 \mathrm{~h}$ even improves the hydrolysis activity of Fe-ZSM5 as reported in our previous investigation [11].

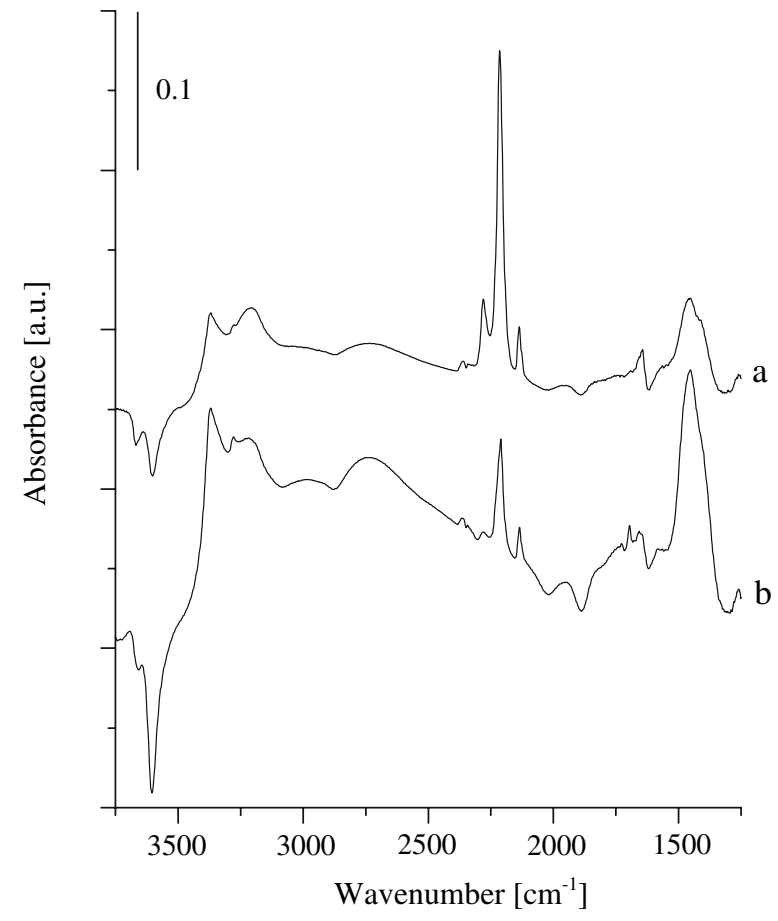

Figure 6. DRIFT spectra of Fe-ZSM5 after (a) HNCO adsorption at $150{ }^{\circ} \mathrm{C}$ for 15 min followed by (b) dosing HNCO and water for $10 \mathrm{~min}$.

The influence of $\mathrm{NO}$ and $\mathrm{NO}_{2}$ on the hydrolysis activity of Fe-ZSM5 was investigated (figure 8), since these two components are present in the exhaust gas of Diesel engines. At high temperatures the $\mathrm{HNCO}$ hydrolysis was not affected, but for $\mathrm{T}<200^{\circ} \mathrm{C}$ the combined addition of $\mathrm{NO}$ and $\mathrm{NO}_{2}$ resulted in a slow decrease of the $\mathrm{HNCO}$ conversion from $\approx 95 \%$ to $\approx 75 \%$ at $175{ }^{\circ} \mathrm{C}$ and from $\approx 65 \%$ to $\approx 40 \%$ at $150{ }^{\circ} \mathrm{C}$. Steadystate conditions were reached only after several minutes 


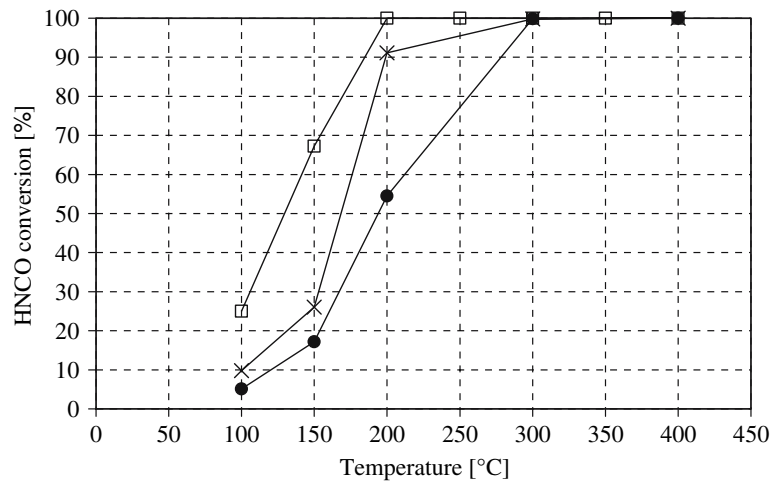

Figure 7. Hydrolysis of $\mathrm{HNCO}$ to $\mathrm{NH}_{3}$ over ( $\square$ ) Fe-ZSM5, (x) $\mathrm{H}-\mathrm{ZSM} 5$, and $(\bullet) \mathrm{Fe}_{2} \mathrm{O}_{3} \cdot \mathrm{S}_{\mathrm{NH}^{3}} 3=100 \%$.

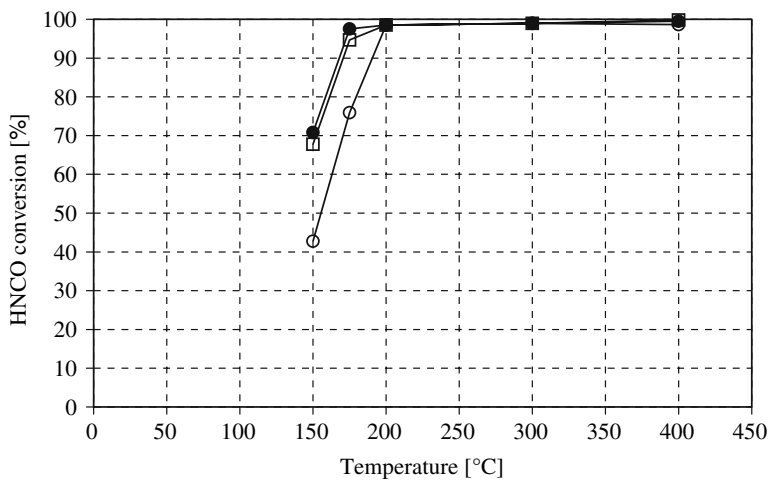

Figure 8. Hydrolysis of HNCO over Fe-ZSM5 ( $\square$ ) without NO and $\mathrm{NO}_{2},(\bullet)$ in the presence of $700 \mathrm{ppm} \mathrm{NO}$ and $(\mathrm{O})$ in the presence of $350 \mathrm{ppm} \mathrm{NO}+350 \mathrm{ppm} \mathrm{NO} \mathrm{NO}_{2} \cdot \mathrm{S}_{\mathrm{NH}} 3=100 \%$.

of $\mathrm{NO}_{2}$ addition. In contrast, the addition of $\mathrm{NO}$ alone even induced a small increase of the HNCO conversion.

\section{Discussion}

The solid-state ion exchange method, chosen in this study, yielded a high iron loading in the final Fe-ZSM5 sample, which is advantageous for its catalytic activity, but resulted also in the formation of various iron species as evidenced by the EPR measurements. The high amount of iron in the zeolite channels caused a considerably reduction of the micropore volume, partly by small iron oxide particles in the range of $20-50 \mathrm{~nm}$, which might have blocked the pores of the catalyst as shown by TEM investigations [23]. It turned out that the formation of different iron species cannot be avoided even when more selective preparation methods with up to 100 times less iron loadings were used (not reported here). Only the formation of iron oxide nanoparticles could be avoided for very low iron loadings. Since the EPR and DRIFT spectra of different samples did not differ in number but only in the intensity of peaks we decided to report and discuss only the spectra of the practically relevant high-exchanged Fe-ZSM5 sample in the present study.

The adsorption of isocyanic acid on Fe-ZSM5 gave rise to the formation of DRIFT bands in the region $2000-2400 \mathrm{~cm}^{-1}$, which were assigned to species on iron oxide, alumina and silica on the catalyst surface. The peak at $\sim 2278 \mathrm{~cm}^{-1}$ evidenced the formation of $\mathrm{Al}-\mathrm{NCO}$ species and, by comparing the spectrum with those obtained for $\mathrm{Fe}_{2} \mathrm{O}_{3} / \mathrm{SiO}_{2}$ and $\mathrm{Fe}_{2} \mathrm{O}_{3} / \mathrm{Al}_{2} \mathrm{O}_{3}$ it becomes clear that the band at $2212 \mathrm{~cm}^{-1}$ arises from the Fe-NCO groups. This conclusion can be drawn in spite of the different nature of these materials, since EPR spectroscopy confirms the formation of similar iron species in Fe-ZSM5, $\mathrm{Fe}_{2} \mathrm{O}_{3} / \mathrm{SiO}_{2}$, and $\mathrm{Fe}_{2} \mathrm{O}_{3} / \mathrm{Al}_{2} \mathrm{O}_{3}$. Due to various iron species detected in Fe-ZSM5 by EPR spectroscopy, different $\mathrm{Fe}-\mathrm{NCO}$ groups are also expected on the surface, and, in fact, the asymmetry of the $\mathrm{Fe}-\mathrm{NCO}$ peaks reported in figures 4 and 5 suggests the presence of several overlapped infrared bands. It should be pointed out that -NCO groups adsorbed on the same transition metal with different oxidation state, e.g. $\mathrm{Fe}^{2+}$ and $\mathrm{Fe}^{3+}$, give rise to different IR signals [30], whereas $\mathrm{Fe}^{2+}$ is EPR silent. Beside the lack of surface sensitivity, this is the main reason why EPR alone is not sufficient to analyze iron containing samples, but should be supplemented by other methods.

It is important to note that the $\mathrm{Fe}-\mathrm{NCO}$ IR signal was always the most intense in the HNCO adsorption region, irrespective of the iron loading (results not shown). No $\mathrm{Si}-\mathrm{NCO}$ band was observed, even when adsorption was performed at $300{ }^{\circ} \mathrm{C}$ and higher. Even after $30 \mathrm{~min}$ of flushing with $\mathrm{HNCO}$, the $\mathrm{Fe}-\mathrm{NCO}$ peaks were still increasing in intensity, thus indicating that the surface was not yet saturated. Interesting enough, Solymosi et al. investigated the HNCO adsorption on $\mathrm{Pt} / \mathrm{SiO}_{2}$ by infrared spectroscopy and found a migration of $-\mathrm{NCO}$ species from the metal centers to silica at room temperature [14]. The same effect was observed for $\mathrm{Cu}$-ZSM5, where-NCO species moved from copper to the silicon in the ZSM5 framework, however at elevated temperatures [12]. Therefore, the temperature at which migration starts indicates the difference in stability of the adsorbed - NCO species on the metal sites compared to the silica sites. Considering these results, the absence of the $\mathrm{Si}-\mathrm{NCO}$ species on FeZSM5 even at $300{ }^{\circ} \mathrm{C}$ suggests that the Fe sites are the most favored for the formation of isocyanate species. The same effect was observed for $\mathrm{Fe}_{2} \mathrm{O}_{3} / \mathrm{SiO}_{2}$.

The adsorption of $\mathrm{HNCO}$ on Fe-ZSM5 at $150{ }^{\circ} \mathrm{C}$ resulted also in the formation of bands typical for adsorbed $\mathrm{NH}_{3}$. Adsorbed $\mathrm{NH}_{3}$ species might arise from traces of $\mathrm{NH}_{3}$ present in the inlet flow or, from the reaction of adsorbed $\mathrm{HNCO}$ with surface $-\mathrm{OH}$ groups. The adsorption of HNCO on Fe-ZSM5 in the presence of water showed that both $\mathrm{Al}-\mathrm{NCO}$ and $\mathrm{Fe}-\mathrm{NCO}$ easily react with water to give $\mathrm{NH}_{3}$. Moreover, no formation of new adsorbed species was observed. 
Performance tests with coated monolith samples showed that the activity Fe-ZSM5 is much higher than that of $\mathrm{Fe}_{2} \mathrm{O}_{3}$, proving that the amount of iron itself is not the only parameter that determines the hydrolysis activity and that the zeolite support is essential for good hydrolysis properties.

The presence of NO in the inlet flow hardly affected the hydrolysis activity of Fe-ZSM5. However, when $\mathrm{NO}_{2}$ was also added, a deactivation effect was observed. This is attributable to the blockage of the active sites by the formation of ammonium nitrate $\left(\mathrm{NH}_{4} \mathrm{NO}_{3}\right)$. In fact, this side-product forms by reaction of $\mathrm{NO}_{2}$ and $\mathrm{NH}_{3}$ at low temperature $[33,34]$. The catalytic activity is then restored at higher temperature due to the decomposition of $\mathrm{NH}_{4} \mathrm{NO}_{3}$, which is melting above $170{ }^{\circ} \mathrm{C}$ and exist in equilibrium with $\mathrm{NH}_{3}$ and $\mathrm{HNO}_{3}$.

\section{Conclusions}

The work reported here shows that the hydrolysis mechanism of HCNO over Fe-ZSM5 agrees with that reported by Solymosi et al. for Cu-ZSM5. DRIFT investigations revealed that at $150{ }^{\circ} \mathrm{C} \mathrm{HNCO}$ adsorbs dissociatively on Fe-ZSM5 forming $\mathrm{Fe}-\mathrm{NCO}$, $\mathrm{Al}-$ $\mathrm{NCO}$, little amounts of $\mathrm{NCO}^{-}$, and probably also $\mathrm{CN}^{-}$ species. The isocyanate species formed on the catalysts readily reacted with water to yield $\mathrm{NH}_{3}$. No formation of additional HNCO adsorbed species was observed in the presence of water. The comparison of the stability of the $-\mathrm{NCO}$ species in the presence of water with the catalytic activity for the $\mathrm{HNCO}$ hydrolysis over Fe-ZSM5 and $\mathrm{Fe}_{2} \mathrm{O}_{3}$ indicated that the -NCO groups are intermediate species in the hydrolysis mechanism of $\mathrm{HNCO}$ over iron-zeolites. The presence of $\mathrm{NO}_{2}$ decreased the catalytic activity, most probably due to the formation of ammonium nitrate species on the catalyst surface.

In the DRIFT spectra of the HNCO adsorption over $\mathrm{SiO}_{2}$ a not yet reported signal at $2186 \mathrm{~cm}^{-1}$ was observed, which was predicted by Ferullo et al. [19] for a $\mathrm{Si}-\mathrm{O}-\mathrm{NCO}$ surface species.

\section{Acknowledgements}

We thank George Mitrikas (Physical Chemistry Laboratory, Swiss Federal Institute of Technology, Zurich, Switzerland) for performing EPR analyses.

\section{References}

[1] P.L.T. Gabrielsson, Top. Catal 28 (2004) 177.

[2] M. Koebel, M. Elsener and M. Kleemann, Catal.Today 59 (2000) 335.

[3] M. Costigan, R. Cary and S. Dobson, Concise International Chemical Assessment Document 29 (Geneva, World Health Organization, 2001).

[4] B. Ramachandran, R.G. Herman, S. Choi, H.G. Stenger, C.E. Lyman and J.W. Sale, Catal. Today 55 (2000) 281.

[5] G. Delahay, D. Valade, A. Guzmán-Vargas and B. Coq, Appl. Catal. B 55 (2005) 149.

[6] G. Qi and R.T. Yang, Appl. Catal. B 60 (2005) 13.

[7] J.A. Sullivan and O. Keane, Appl. Catal. B 61 (2005) 244.

[8] R.Q. Long and R.T. Yang, J. Catal. 188 (1999) 332.

[9] Q. Sun, Z.-X. Gao, H.-Y. Chen and W.M.H. Sachtler, J. Catal. 201 (2001) 89.

[10] C.A. Jones, D. Stec and S.C. Larsen, J. Mol. Catal. A 212 (2004) 329.

[11] G. Piazzesi, M. Devadas, O. Kröcher, M. Elsener and A. Wokaun, Catal. Commun 7 (2006) 600.

[12] F. Solymosi and T. Bánsági, J. Catal 156 (1995) 75.

[13] N. Bion, J. Saussey, C. Hedouin, T. Seguelong and M. Daturi, Phys.Chem. Chem. Phys 3 (2001) 4811.

[14] F. Solymosi and T. Bánsági, J. Phys. Chem 83 (1979) 552.

[15] F. Acke, B. Westerberg and M. Skoglundh, J. Catal 179 (1998) 528.

[16] F. Solymosi, L. Völgyesi and J. Sárkány, J. Catal 54 (1978) 336.

[17] A.D. Cowan, N.W. Cant, B.S. Haynes and P.F. Nelson, J. Catal 176 (1998) 329.

[18] T. Bánsági, J. Raskó, F. Solymosi, in: Proceedings of the international symposium on spillover of adsorbed species (Lyon-Villeurbanne, 1983) pp. 109.

[19] R.M. Ferullo and N.J. Castellani, J. Mol. Catal. A 221 (2004) 155.

[20] I.O.Y. Liu, N.W. Cant, M. Kögel and T. Turek, Catal. Lett 63 (1999) 241.

[21] M. Kleemann, M. Elsener, M. Koebel and A. Wokaun, Ind. Eng. Chem. Res 39 (2000) 4120.

[22] O. Kröcher, M. Elsener and M. Koebel, Anal. Chim. Acta 537 (2005) 393.

[23] M. Devadas, O. Kröcher, M. Elsener, A. Wokaun, G. Mitrikas, N. Söger, M. Pfeifer, Y. Demel and L. Mussmann, Catal. Today 119 (2007) 137.

[24] E.A. Zhilinskaya, G. Delahay, M. Mauvezin, B. Coq and A. Aboukaïs, Langmuir 19 (2003) 3596.

[25] T. Kobayashi, N. Guilhaume, J. Miki, N. Kitamura and M. Haruta, Catal. Today 32 (1996) 171.

[26] A. Parmaliana, F. Arena, F. Frusteri, A. Martínez-Arias, M. López Granados and J.L.G. Fierro, Appl. Catal. A 226 (2002) 163.

[27] C. Reid, J. Chem. Phys 18 (1950) 1544.

[28] M.L. Unland, J. Phys. Chem 77 (1973) 1952.

[29] V.A. Matyshak and O.V. Krylov, Catal. Today 25 (1995) 1.

[30] G. Qi, J.E. Gatt and R.T. Yang, J. Catal 226 (2004) 120.

[31] F. Solymosi and J. Raskó, J. Catal. 65 (1980) 235.

[32] F. Solymosi and T. Bánsági, J. Catal 202 (2001) 205.

[33] G. Madia, M. Koebel, M. Elsener and A. Wokaun, Ind. Eng. Chem. Res 41 (2002) 4008.

[34] G. Piazzesi, M. Elsener, O. Kröcher and A. Wokaun, Appl. Catal. B 65 (2006) 169. 